\title{
MEMPELAJARI KARAKTERISTIK FISIK BIJI KAKAO (Theobrema cacao L.) PADA SUHU PENGERINGAN YANG BERBEDA
}

\section{PHYSICAL CHARACTERISTICS OF COCOA SEEDS (Theobrema cacao L.) AT DIFFERENT DRYING TEMPERATURES}

\author{
Sri Waluyo ${ }^{1 凶}$, Tri Wahyu Saputra ${ }^{2}$, Nikita Permatahati ${ }^{1}$ \\ ${ }^{1}$ Jurusan Teknik Pertanian, Fakultas Pertanian, Universitas Lampung \\ ${ }_{2}^{2}$ Program Studi Agroteknologi, Fakultas Pertanian, Universitas Jember \\ ${ }^{\otimes}$ Komunikasi Penulis, email: sri.waluyo@fp.unila.ac.id \\ DOI:http://dx.doi.org/10.23960/jtep-lv10i2.200-208
}

Naskah ini diterima pada 25 Februari 2021; revisi pada 20 Maret 2021; disetujui untuk dipublikasikan pada 8 April 2021

\begin{abstract}
Drying is a common process step for agricultural grain products for ease of handling and for achieving the desired quality levels. One of the commodities that has high economic value produced by farmers in Lampung Province is cocoa beans. The drying process may change the physical properties of the cocoa beans and affect the processing of cocoa beans at a later stage. This study aims to determine the effect of drying temperature on changes in the physical properties of cocoa beans such as dimension, volume, weight, surface area, true density, bulk density, porosity, sphericity, and angle of repose. This research was applied to fresh non-fermented cocoa beans in testing. The cocoa beans were dried at temperatures of 40,50 or $60^{\circ} \mathrm{C}$. The research data were then statistically tested using paired sample T-Test at the 95\% level to determine whether there is any effect of drying temperature on changes in its physical properties. The results showed a significant effect of drying temperature on weight, volume, geometric mean diameter ( $\mathrm{Dg}$ ), surface area, bulk density, porosity, and angle of repose of cocoa beans. Meanwhile, the sphericity and true density parameters did not significantly change.
\end{abstract}

\section{Keywords: cocoa beans, drying, physical properties}

\begin{abstract}
ABSTRAK
Pengeringan merupakan langkah proses yang umum dilakukan pada produk biji-bijian hasil pertanian untuk kemudahan penanganan dan mencapai tingkat kualitas yang diinginkan. Salah satu komoditas yang memiliki nilai ekonomi cukup tinggi yang dihasilkan oleh petani di Provinsi Lampung adalah biji kakao atau sering juga disebut biji coklat. Proses pengeringan kemungkinan dapat mengubah sifat fisik biji kakao dan mempengaruhi pengolahan biji kakao pada tahap selanjutnya. Penelitian ini bertujuan untuk mengetahui pengaruh suhu pengeringan terhadap perubahan sifat fisik biji kakao seperti dimensi, volume, berat, luas permukaan, true density, bulk density, porositas, sphericity, angle of repose, dan kadar air. Biji kakao dikeringkan masing-masing pada suhu yaitu 40,50 , dan $60^{\circ} \mathrm{C}$. Data hasil penelitian kemudian diuji secara statistik menggunakan paired sample T-Test pada taraf 95\%. untuk mengetahui ada tidaknya pengaruh suhu pengeringan terhadap perubahan sifat fisiknya. Hasil penelitian memperlihatkan adanya pengaruh nyata suhu pengeringan terhadap berat, volume, geometric mean diameter (Dg), luas permukaan, bulk density, porositas, dan angle of repose. Sementara itu, parameter sphericity dan true density tidak signifikan berubah.
\end{abstract}

Kata Kunci: kakao, pengeringan, sifat fisik

\section{PENDAHULUAN}

Kakao (Theobrema cacao L.) merupakan bahan baku agroindustri penting yang dihasilkan oleh banyak petani di Provinsi Lampung. Jumlah produksi kakao Provinsi Lampung mencapai
58.173 ton, merupakan provinsi urutan ketiga dengan produktivitas tertinggi secara nasional, dan mayoritas produksinya $(97,29 \%)$ diperoleh melalui perkebunan rakyat (BPS, 2019). Dengan demikian, kakao merupakan komoditi sub sektor perkebunan yang memiliki nilai strategis. 
Berdasarkan data BPS (2019), hampir separo (46,3\%) produksi kakao Indonesia diekspor dalam bentuk biji maupun turunannya. Untuk dapat diekspor atau pun untuk mendapatkan harga penjualan yang lebih tinggi, biji kakao harus memenuhi beberapa persyaratan mutu SNI 2323:2008, misalnya kadar air, kadar kotoran, dan ada tidaknya kontaminan dari serangga, jamur dan mitotoksin (BSN, 2008).

Pengeringan adalah salah satu langkah penanganan pasca panen yang dapat menentukan kualitas biji kakao terutama dalam hal fisik, cita rasa, dan aroma (Lasisi, 2014). Pengeringan kakao biasanya ditujukan untuk mengurangi kadar air biji hingga batas yang aman selama transportasi dan penyimpanan, yaitu di bawah 7,5\% (Permentan RI, 2014). Dengan menurunnya kandungan air bahan, dapat mengurangi aktivitas bakteria dan pertumbuhan jamur (Deus et al., 2018; Tardzenyuy et al., 2020) sehingga pada tataran tertentu dapat memenuhi persyaratan sebagaimana dinyatakan pada Permentan RI No 67 Tahun 2014. Selain itu, selama pengeringan struktur seluler bahan mungkin berubah dan mengubah karakteristik sifat fisik bahan. Sementara itu, pengetahuan tentang sifat fisik menjadi penting dalam evaluasi kualitas bahan pangan dan seringkali berhubungan dengan keamanan pangan dan mutu dan daya tumbuh biji benih (Filho et al., 2016; Siddique dan Wright, 2003). Pengetahuan tentang sifat fisik makanan membantu dalam memprediksi perilaku bahan baku baru (Anyidoho, 2015). Informasi tentang sifat fisik bahan pangan juga diperlukan dalam desain mesin yang digunakan selama panen, pemilahan, pembersihan, penanganan dan penyimpanan (Shitanda, et al., 2002). Parameter sifat fisik yang umum digunakan untuk karakterisasi biji kakao dan evaluasi kualitasnya meliputi ukuran, berat, sphericity, volume, luas permukaan, bulk density, true density, porositas, kadar air, dan angle of repose. Informasi yang berkaitan dengan porositas dan berat jenis produk biji-bijian sangat penting untuk studi yang melibatkan perpindahan panas dan massa serta pergerakan udara melalui butiran curah. Selain itu, bersama dengan kadar air, volume, berat jenis dan porositas merupakan parameter dasar untuk mempelajari pengeringan dan penyimpanan produk pertanian dan untuk melihat kualitas bahan yang hilang atau berubah hingga waktu pemasarannya.

Mengingat begitu pentingnya pengetahuan tentang sifat fisik produk pertanian mulai dari saat pemanenan, pengangkutan, desain dan dimensi ruang penyimpanan, pembuatan dan pengoperasian peralatan proses menjadi dasar pertimbangan utama dilakukannya penelitian ini. Pengeringan juga memungkinkan terjadinya perubahan fisik, perilaku biokimia, dan pada akhirnya berpengaruh pada kualitas produk yang dikeringkan. Penelitian ini bertujuan untuk mempelajari pengaruh suhu pengeringan terhadap perubahan sifat fisik biji kakao non fermentasi.

\section{BAHAN DAN METODE}

Peralatan yang digunakan dalam penelitian ini adalah timbangan digital, unit pengering (tipe rak), termometer, jangka sorong (0,01 digit), cawan, gelas ukur $1000 \mathrm{ml}$ dan $500 \mathrm{ml}$, alat pengukur sudut baring (angle of repose), dan oven. Bahan yang digunakan sebagai eksperimen adalah biji kakao segar non fermentasi yang diperoleh dari petani di wilayah Kabupaten Tanggamus.

\subsection{Prosedur Penelitian}

\subsubsection{Pengukuran Parameter Fisik Biji Kakao}

Perubahan parameter fisik biji kakao setelah pengeringan selama 8,5 jam diamati dan kemudian dibandingkan dengan parameter fisik bahan sebelum pengeringan. Parameter fisik yang diukur adalah:

\section{Berat Satuan Biji Kakao}

Sebanyak 5 biji kakao diambil secara acak untuk dilakukan penimbangan berat satuan. Langkah ini diulang sebanyak 3 kali untuk setiap kelompok perlakuan sehingga total sampel yang digunakan adalah 15 biji.

\section{Dimensi Satuan Biji atau Geometric Mean Diameter dan Sphericity}

Sebanyak 5 biji kakao diambil secara acak kemudian diukur dimensi panjang (L), lebar (W), dan tebal (T) dengan jangka sorong. Selanjutnya, geometric mean diameter dan 
sphericity dihitung dengan persamaan (Mohsenin, 1986):

$$
\begin{aligned}
D g & =(L W T)^{1 / 3} \\
\varphi & =\frac{D g}{L} x 100
\end{aligned}
$$

dimana, $\mathrm{D}_{\mathrm{g}}$ adalah geometric mean diameter $(\mathrm{mm}), \mathrm{L}$ adalah diameter terpanjang $(\mathrm{mm}), \mathrm{W}$ adalah diameter tegak lurus dengan $\mathrm{L}(\mathrm{mm}), \mathrm{T}$ adalah diameter terpanjang dan tegak lurus terhadap L dan W (mm), dan $\varphi$ adalah sphericity (\%)

\section{Volume dan Luas Permukaan Satuan Biji Kakao}

Hasil pengukuran dimensi di atas dapat pula digunakan untuk menghitung besarnya volume dan luas permukaan. Persamaan yang digunakan adalah sebagai berikut (Jain dan Bal, 1997):

$$
\begin{aligned}
\mathrm{V} & =\frac{\pi B^{2} L^{2}}{6(2 L-B)} \\
\mathrm{S} & =\frac{\pi B L^{2}}{2 L-B} \\
\mathrm{~B} & =(W T)^{1 / 2}
\end{aligned}
$$

Dimana, $\mathrm{V}$ adalah volume $\left(\mathrm{mm}^{3}\right), \mathrm{S}$ adalah luas Permukaan $\left(\mathrm{mm}^{2}\right)$, dan B adalah diameter bagian bulat dari biji-bijian ( $\mathrm{mm}$ ).

\section{Angle of Repose}

Sebanyak 500 gram sampel biji kakao dimasukkan ke dalam kotak bercorong untuk diukur sudut baringnya (angle of repose). Ketinggian mulut corong dengan permukaan meja eksperimen adalah $25 \mathrm{~cm}$. Setelah seluruh sampel keluar corong maka akan terbentuk gundukan bahan berbentuk kerucut. Diameter dasar kerucut (D) dan tinggi kerucut (H) kemudian diukur menggunakan penggaris. Angle of repose dihitung dengan persamaan (Kaleemullah dan Kailappan, 2003):

$$
\varphi=\tan ^{-1} \frac{2 h}{D}
$$

\section{Bulk Density}

Bulk density dihitung dengan mengukur berat sampel pada volume sampel yang diketahui. Sampel dimasukkan ke dalam gelas ukur 1000 $\mathrm{ml}$ sampai rata permukaan gelas. Berat sampel tersebut kemudian ditimbang. Ekspresi persamaan hitung bulk density adalah sebagai berikut (Mohsenin, 1986):

$$
\rho_{b}=\frac{m_{b}}{v}
$$

Dimana, $\rho_{\mathrm{b}}$ adalah bulk density $\left(\mathrm{g} / \mathrm{cm}^{3}\right), \mathrm{m}_{\mathrm{b}}$ adalah berat bahan curah $(\mathrm{g})$, dan v adalah volume total atau terukur $\left(\mathrm{cm}^{3}\right)$

\section{True Density}

Sebanyak 250 gram biji kakao dijatuhkan ke dalam gelas ukur (kapasitas $1000 \mathrm{ml}$ ) yang berisi air dengan volume $500 \mathrm{ml}$. Setelah seluruh biji kakao mengendap dalam gelas ukur, kenaikan volume dicatat. True density dihitung menggunakan persamaan sebagai berikut (Anisum, 2016):

$$
\rho_{t}=\frac{m_{s}}{v_{d}}
$$

Dimana, $\rho_{\mathrm{t}}$ adalah true density $\left(\mathrm{g} / \mathrm{cm}^{3}\right), \mathrm{m}_{\mathrm{s}}$ adalah berat sampel $(\mathrm{g})$, dan $\mathrm{v}_{\mathrm{d}}$ adalah kenaikan volume (volume awal - volume akhir) $\left(\mathrm{cm}^{3}\right)$

\section{Porositas}

Porositas bahan dapat dihitung dengan mengetahui nilai bulk density dan true density sebagaimana dinyatakan oleh Jain dan Bal (1997) :

$$
\varepsilon=\frac{(\rho t-\rho b)}{\rho t} x 100
$$

\section{Kadar Air}

Kadar air ditentukan dengan metode gravimetrik. Persamaan hitung kadar air adalah sebagai berikut (Divekar, et al, 2011):

$$
K A(d . b)=\frac{\mathrm{m} 1-\mathrm{m} 2}{\mathrm{~m} 1} x 100 \%
$$

Dimana, KA(d.b) adalah kadar air basis basah $(\%), \mathrm{m}_{1}$ adalah berat sampel awal (g), dan $\mathrm{m}_{2}$ adalah berat sampel di akhir pengeringan (g)

\subsubsection{Pengeringan Biji Kakao}

Sebanyak total 9 kg biji kakao segar (sekitar 1 kg untuk setiap unit percobaan) dikeringkan dengan pengering tipe rak pada tiga variasi perlakukan suhu, yaitu 40,50 , dan $60^{\circ} \mathrm{C}$. Pengeringan dilakukan selama 8,5 jam, setiap 30 menit sampel biji kakao ditimbang untuk mengetahui penurunan berat bahan. 


\subsection{Analisis Data}

Hasil pengukuran parameter fisik biji kakao sebelum dan sesudah pengeringan dibandingkan dan diuji secara statistik menggunakan metode paired sample t-test. Uji ini digunakan untuk mengetahui perbedaan nilai rerata parameter dari dua sampel yang berpasangan. Hasil keputusan uji metode ini yaitu: (i) jika nilai Sig. (2-tailed) $<0,05$ maka terdapat perbedaan yang signifikan, atau (ii) jika nilai Sig. (2-tailed) > 0,05 maka tidak terdapat perbedaan yang signifikan.

\section{HASIL DAN PEMBAHASAN}

\subsection{Karakteristik Pengeringan}

Seluruh nilai parameter fisik biji kakao sebelum dan setelah pengeringan ditabulasikan pada Tabel 1. Sampel biji kakao segar yang digunakan memiliki kadar air rerata sebesar 57,23\%. Penurunan kadar air selama pengeringan pada tiga suhu yang berbeda ditunjukkan sebagaimana Gambar 1. Pola penurunan kadar air yang terjadi dapat dibagi menjadi dua segmen. Pengeringan hingga 3 jam pertama berjalan dengan lebih cepat untuk keseluruhan suhu pengeringan. Penurunan kadar air pada pengeringan dengan suhu 50 dan $60^{\circ} \mathrm{C}$ cukup signifikan yaitu berturut-turut menjadi berkisar 25 dan 22\%. Artinya hampir separo kandungan air awalnya telah teruapkan. Sedangkan untuk suhu $40^{\circ} \mathrm{C}$ penurunan kadar air sedikit lebih kecil menjadi berkisar 35\%. Selanjutnya, pola laju pengeringan berubah menjadi lebih lambat. Dalam rentang waktu pengeringan yang sama
(3 jam), perubahan kadar air bahan relatif kecil dan bahkan menuju konstan. Tercatat bahwa pada periode waktu pengeringan 5,5 sampai dengan 8,5 jam, pengeringan dengan suhu 40,50, dan $60{ }^{\circ} \mathrm{C}$ kadar air bahan hanya menurun sebesar berturut-turut 2,83; 1,4; dan 3,88\%. Karakteristik pengeringan ini mengikuti pola umum untuk pengeringan biji-bijian. Semakin tinggi suhu, semakin besar driving force untuk terjadinya aliran air dari dalam bahan menuju lapisan yang lebih luar dan selanjutnya teruapkan (Desrosier, 1988; Siddique dan Wright, 2003; Ndukwu, 2009; Suherman, et al., 2012).

\subsection{Ukuran atau Geometric Mean Diameter $(D g)$}

Keluarnya kandungan air dalam bahan karena proses pengeringan dilaporkan mempengaruhi karakteristik sifat fisik dan kimia bahan. Sebagaimana ditunjukkan pada Gambar 1, semakin tinggi suhu, waktu pendek yang dibutuhkan untuk mencapai kadar air pengeringan yang diinginkan. Namun demikian, kecepatan perubahan kandungan air di dalam bahan diikuti dengan perubahan sifat fisik lainnya. Hasil pengukuran menunjukkan bahwa setelah proses pengeringan biji kakao mengalami penurunan geometric mean diameter $(\mathrm{Dg})$. Pada suhu pengeringan 40,50 , dan $60^{\circ} \mathrm{C}$ terjadi penurunan geometric mean diameter $(\mathrm{Dg})$ dari berturut-turut $18,23 \mathrm{~mm}, 15,26 \mathrm{~mm}$ dan 16,53 mm menjadi $14,26 \mathrm{~mm}, 13,93 \mathrm{~mm}$, dan 13,67 $\mathrm{mm}$. Suhu pengeringan yang lebih rendah menampakkan penyusutan dimensi yang lebih rendah sehingga perubahan Dg-nya lebih kecil.

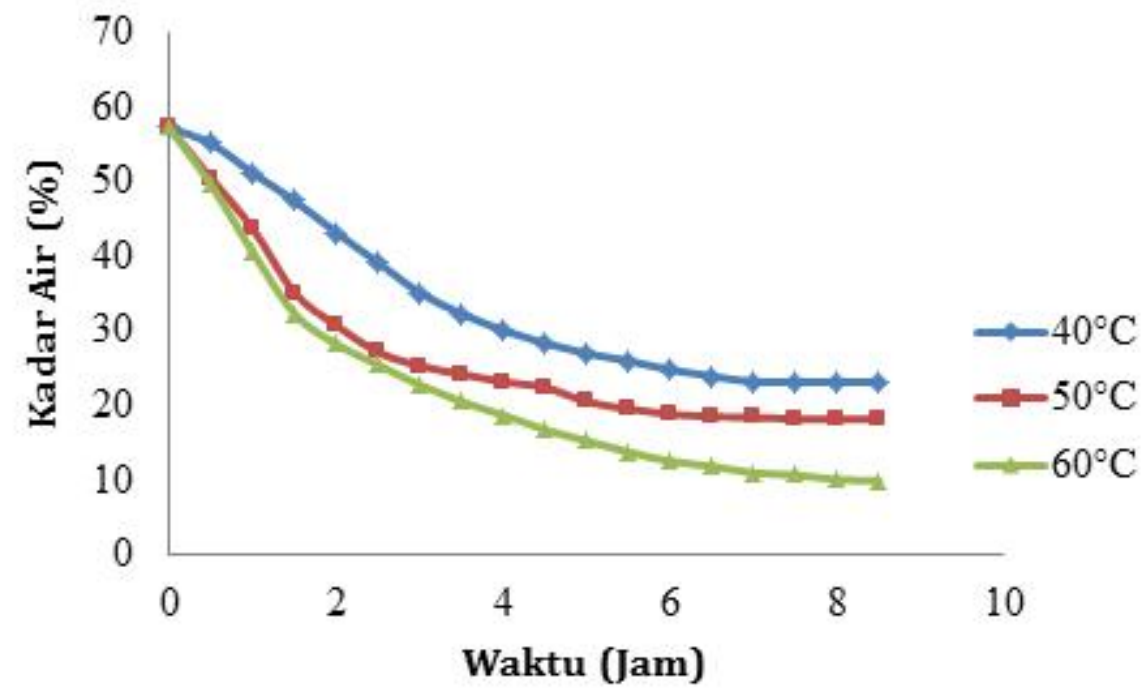

Gambar 1. Kurva Penurunan Kadar Air Selama Pengeringan pada 3 Tingkat Suhu yang Berbeda 
Tabel 1. Sifat Fisik Biji Kakao Segar dan Setelah 8,5 Jam Pengeringan pada Berbagai Suhu

\begin{tabular}{|c|c|c|c|c|c|c|c|c|}
\hline \multirow{2}{*}{ Parameter } & \multirow{2}{*}{$\begin{array}{c}\text { Suhu } \\
\left({ }^{\circ} \mathrm{C}\right)\end{array}$} & \multirow{2}{*}{$\mathbf{N}$} & \multicolumn{3}{|c|}{ Sebelum Pengeringan } & \multicolumn{3}{|c|}{ Sesudah 8,5 jam Pengeringan } \\
\hline & & & Min. & Maks. & Rerata & Min. & Maks. & Rerata \\
\hline \multirow{3}{*}{$\begin{array}{l}\text { Geometric mean } \\
\text { diameter }(\mathrm{Dg}) \\
(\mathrm{mm})\end{array}$} & 40 & 15 & 13,55 & 18,23 & $15,38^{\mathrm{a}}$ & 13,05 & 15,65 & $14,26^{\mathrm{b}}$ \\
\hline & 50 & 15 & 14,23 & 15,26 & 14,57 a & 11,88 & 15,46 & $13,93^{b}$ \\
\hline & 60 & 15 & 12,99 & 16,53 & $14,54^{\mathrm{a}}$ & 12,10 & 15,34 & $13,67^{b}$ \\
\hline \multirow{3}{*}{ Sphericity } & 40 & 15 & 0,50 & 0,60 & $0,55^{*}$ & 0,45 & 0,60 & $0,52^{*}$ \\
\hline & 50 & 15 & 0,54 & 0,62 & $0,57^{*}$ & 0,53 & 0,62 & $0,56^{*}$ \\
\hline & 60 & 15 & 0,51 & 0,59 & $0,55^{*}$ & 0,49 & 0,60 & $0,54^{*}$ \\
\hline \multirow{3}{*}{ Volume $\left(\mathrm{mm}^{3}\right)$} & 40 & 15 & 802,5 & 2057,9 & $1219,61^{a}$ & 719,1 & 1212,0 & $942,02^{b}$ \\
\hline & 50 & 15 & 906,8 & 1176,4 & $1032,33^{a}$ & 664,6 & 1254,3 & $907,79 \mathrm{~b}$ \\
\hline & 60 & 15 & 654,9 & 1480,7 & $1035,05^{a}$ & 227,4 & 939,2 & $593,68^{b}$ \\
\hline \multirow{3}{*}{$\begin{array}{l}\text { Luas Permukaan } \\
\left(\mathrm{mm}^{2}\right)\end{array}$} & 40 & 15 & 526,6 & 877,7 & $633,74^{a}$ & 490,6 & 662,4 & $548,31^{b}$ \\
\hline & 50 & 15 & 518,5 & 615,8 & $563,03^{a}$ & 376,7 & 631,0 & $516,96^{b}$ \\
\hline & 60 & 15 & 420,2 & 729,0 & $567,27^{a}$ & 127,2 & 532,9 & $355,97^{b}$ \\
\hline \multirow{3}{*}{ Angle of repose } & 40 & 3 & 32,24 & 40,83 & $36,18^{a}$ & 27,76 & 32,85 & $30,45^{b}$ \\
\hline & 50 & 3 & 34,56 & 38,58 & $36,34^{\mathrm{a}}$ & 28,35 & 32,72 & $30,52^{b}$ \\
\hline & 60 & 3 & 35,23 & 44,92 & $39,17^{a}$ & 20,90 & 29,04 & $25,15^{b}$ \\
\hline \multirow{3}{*}{$\begin{array}{l}\text { Bulk density } \\
\left(\mathrm{g} / \mathrm{mm}^{3}\right)\end{array}$} & 40 & 3 & 0,72 & 0,76 & $0,74^{\mathrm{a}}$ & 0,51 & 0,53 & $0,52^{b}$ \\
\hline & 50 & 3 & 0,72 & 0,74 & $0,73^{a}$ & 0,46 & 0,68 & $0,56^{\mathrm{b}}$ \\
\hline & 60 & 3 & 0,69 & 0,71 & $0,70^{\mathrm{a}}$ & 0,48 & 0,52 & $0,49 \mathrm{~b}$ \\
\hline \multirow{3}{*}{$\begin{array}{l}\text { True density } \\
\left(\mathrm{g} / \mathrm{mm}^{3}\right)\end{array}$} & 40 & 3 & 1,05 & 1,06 & $1,06^{*}$ & 1,04 & 1,10 & $1,08^{*}$ \\
\hline & 50 & 3 & 1,05 & 1,06 & $1,05^{*}$ & 1,00 & 1,05 & $1,03^{*}$ \\
\hline & 60 & 3 & 1,05 & 1,05 & $1,05^{*}$ & 0,97 & 1,19 & $1,07^{*}$ \\
\hline \multirow{3}{*}{ Porositas (\%) } & 40 & 3 & 27,27 & 32,39 & $29,69^{a}$ & 51,02 & 53,54 & $52,21^{b}$ \\
\hline & 50 & 3 & 29,41 & 31,43 & $30,76^{a}$ & 35,14 & 53,70 & $45,56^{b}$ \\
\hline & 60 & 3 & 32,39 & 34,25 & $33,32^{\mathrm{a}}$ & 45,83 & 59,62 & $53,39^{b}$ \\
\hline
\end{tabular}

Keterangan : 1) $\mathrm{N}$ adalah jumlah ulangan atau jumlah unit sampel dan 2) Perbedaan huruf pada baris yang sama menunjukkan perbedaan nyata hasil uji paired sample T-test pada nilai $\mathrm{p}<0,05$.

Hal ini sejalan dengan Culver dan Wrolstad, (2008) yang menyatakan bahwa selama proses pengeringan bahan, tranformasi fisik bentuk dan ukuran berat bahan mengalami perubahan. Laju perubahan ini berbanding lurus dengan lama proses pengeringan. Nilai uji sample paired Ttest menghasilkan nilai $0,000<0,05$. Ini berarti bahwa ada perbedaan yang signifikan antara pengukuran geometric mean diameter $(\mathrm{Dg})$ sebelum dan sesudah pengeringan.

\subsection{Sphericity}

Berkurangnya kandungan air dalam bahan, kemudian diikuti oleh perubahan dimensi pada seluruh orientasi produk. Perubahan-perubahan ini akan menentukan dalam perhitungan parameter kebulatan (sphericity) produk. Sphericity biji kakao sebelum dan setelah dikeringkan secara statistik menunjukkan tidak ada perubahan signifikan. Sphericity biji kakao yang relatif tetap sebelum dan setelah pengeringan mengindikasikan bahwa perubahan dimensi produk secara relatif seimbang pada keseluruhan orientasi biji. Pada suhu pengeringan 40,50 , dan $60^{\circ} \mathrm{C}$ didapatkan nilai sphericity biji kakao kering berturut-turut sebesar 0,52, 0,56, dan 0,54. Dengan nilai sphericity pada kisaran 0,5 maka dapat dikatakan diameter terpanjang biji kakao kirakira dua kali diameter terpendeknya. Secara umum dapat dikatakan bentuk biji kakao adalah lonjong (ellips). Dasar penetapan ini mengikuti (Murad, et al., 2015), yang pernyataan bahwa nilai kebulatan mendekati 1 berarti bahan tersebut bentuknya mendekati bola (bulat).

\subsection{Volume dan Luas Permukaan Biji}

Dampak perubahan kadar air bahan telah nyata berpengaruh pada berubahnya dimensi yang semakin kecil, diperkuat dengan hasil perhitungan volume dan luas permukaan biji. Volume dan luas permukaan biji kakao mengalami penurunan setelah dilakukan proses pengeringan. Penurunan volume terjadi pada ketiga variasi suhu $\left(40,50\right.$, dan $\left.60^{\circ} \mathrm{C}\right)$ masing masing berturut-turut sebesar $942,02 \mathrm{~mm}^{3}$, 
$907,79 \mathrm{~mm}^{3}$, dan 593,68 $\mathrm{mm}^{3}$. Sedangkan penurunan luas permukaan berurutan memiliki rata - rata sebesar $548,31 \mathrm{~mm}^{2}, 516,96 \mathrm{~mm}^{2}$, dan $355,97 \mathrm{~mm}^{2}$. Pada suhu pengeringan 40 dan $50^{\circ} \mathrm{C}$ penurunan volume dan luas permukaan yang terjadi tidak terlalu besar jika dibandingkan dengan perubahan volume dan luas permukaan biji kakao pada suhu pengeringan $60^{\circ} \mathrm{C}$. Hal ini membuktikan bahwa suhu pengeringan menjadi salah satu faktor penentu terjadinya perubahan volume biji dan luas permukaannya. Menurut Andasuryani, et al. (2015), perubahan volume dan luas permukaan biji kakao lebih dipengaruhi oleh dimensi aksial biji kakao dibandingkan dengan diameter ekuatornya. Lebih lanjut Risdianti, et al. (2016) melaporkan bahwa penurunan massa bahan serta kadar air dapat menyebabkan berkurangnya luas permukaan bahan. Keluarnya massa air dari dalam bahan menyebabkan berkurangnya berat bahan serta seringkali diikuti mengkerutnya struktur seluler bahan. Dengan demikian, maka volume bahan pun mengalami penurunan. Menurunnya volume biji seringkali dihubungkan dengan terjadinya shrinkage (Koua et al., 2017) dimana nilainya dipengaruhi oleh suhu pengeringan (Ndukwu, et al., 2012; Senadeera, et al., 2020). Hasil uji paired sample T-Test pada parameter volume diperoleh nilai p sebesar $0,012<0,05$. Sedangkan untuk parameter luas permukaan nilai p sebesar 0,041 $<0,05$. Dengan demikian dapat disimpulkan bahwa terdapat perbedaan yang signifikan antara pengukuran luas permukaan dan volume untuk sebelum dan sesudah pengeringan.

\subsection{Angle of Repose}

Menurunnya kadar air dan berubahnya karakteristik permukaan bahan berpengaruh pada sifat aliran bahan. Pada suhu pengeringan $40^{\circ} \mathrm{C}, 50^{\circ} \mathrm{C}$, dan $60^{\circ} \mathrm{C}$ diperoleh nilai rata - rata angle of repose sesudah pengeringan sebesar $30,45^{\circ}, 30,52^{\circ}$, dan $22,15^{\circ}$. Nilai-nilai ini lebih kecil dibandingkan angle of repose biji kakao kondisi basah. Kadar air dan kehalusan permukaan berpengaruh pada hasil pengukuran angle of repose sebagaimana dinyatakan oleh Pangaribuan, et al. (2016). Parameter lain yang berpengaruh terhadap besarnya angle of repose suatu bahan massa jenis, luas permukaan dan koefisien gesekan. Dengan semakin keringnya bahan dan lebih halusnya permukaan maka gaya kohesi partikel bahan semakin kecil (Carr, 1976, dalam Syah, et al., 2013). Bahan yang memiliki gaya kohesi tinggi artinya bahan tersebut kurang dapat bergerak secara bebas sehingga dapat membentuk sudut baring yang besar. Sedangkan bahan dengan gaya kohesi yang rendah maka sudut baringnya lebih kecil. Hasil uji paired sample T-Test pada pengukuran angle of repose pada biji kakao menunjukkan nilai sebesar 0,007 $<0,05$ sehingga dapat disimpulkan bahwa terdapat perbedaan yang signifikan antara pengukuran angle of repose sebelum dan sesudah pengeringan.

\subsection{Bulk Density dan True Density}

Pada penelitian ini didapatkan data rata - rata nilai bulk density setelah pengeringan pada suhu $40^{\circ} \mathrm{C}, 50^{\circ} \mathrm{C}$, dan $60^{\circ} \mathrm{C}$ sebesar $0,52,0,56$, dan 0,49 . Nilai bulk density ini dipengaruhi oleh ukuran bahan dan kadar air. Hasil uji paired sample TTest pada bulk density biji kakao menunjukkan nilai $0,000<0,05$ sehingga dapat disimpulkan bahwa terdapat perbedaan yang signifikan antara pengukuran bulk density sebelum dan sesudah pengeringan.

Rata-rata nilai true density pada sesudah pengeringan untuk suhu $40^{\circ} \mathrm{C}, 50^{\circ} \mathrm{C}$, dan $60^{\circ} \mathrm{C}$ berturut-turut sebesar 1,08, 1,03 dan 1,07. Berdasarkan data tersebut terjadi kenaikan dan penurunan pada nilai true density setelah proses pengeringan. Untuk suhu $40^{\circ} \mathrm{C}$ dan $60^{\circ} \mathrm{C}$ terjadi kenaikan nilai rata-rata true density sedangkan pada suhu $50^{\circ} \mathrm{C}$ terjadi penurunan nilai rata-rata true density. Hal tersebut dapat disebabkan karena perbedaan massa dan volume yang didapatkan pada setiap variasi suhu. Hasil yang diperoleh dari uji paired sample T-test menyatakan bahwa terdapat perbedaan yang tidak signifikan antara pengukuran true density sebelum dan sesudah pengeringan yang ditunjukkan dari nilai yang didapatkan sebesar 0,681 atau $<0,05$.

\subsection{Porositas}

Pada suhu $40^{\circ} \mathrm{C}, 50^{\circ} \mathrm{C}$, dan $60^{\circ} \mathrm{C}$ didapatkan hasil rata -rata porositas sesudah pengeringan berturut-turut sebesar $52,21,45,56 \%$, dan $53,39 \%$. Berdasarkan hal tersebut terjadi kenaikan dan penurunan nilai porositas pada setiap variasi suhu. Hal ini disebabkan karena sebelum pengeringan masih terdapat pulp pada biji kakao sehingga rongga antar biji lebih padat 
yang menyebabkan nilai porositas lebih tinggi dibandingkan dengan setelah pengeringan. Faktor lainnya dikarenakan pada pengukuran true density dan bulk density sampel biji kakao pada setiap ulangan yang diambil secara random sehingga bentuk biji kakao pun tidak seragam. Hal ini diperkuat dengan pernyataan (Chakraverty dan Singh, 2001) yang mengatakan bahwa porositas tergantung pada bentuk, dimensi, dan kekasaran permukaan biji - bijian. Data tersebut kemudian dianalisis dengan uji paired sample T-Test yang menghasilkan nilai uji sebesar 0,000 $<0,05$ sehingga dapat dijelaskan bahwa ada perbedaan yang signifikan pada porositas biji kakao antara sebelum dan sesudah pengeringan.

\section{KESIMPULAN}

Suhu pengeringan menjadi driving force terjadinya penguapan air dari dalam bahan dan diikuti dengan perubahan fisik produk. Perubahan kadar air setelah pengeringan pada suhu antara 40 dan $60^{\circ} \mathrm{C}$ memiliki pengaruh yang signifikan terhadap perubahan sifat fisik biji kakao seperti berat, ukuran atau geometric mean diameter $(\mathrm{Dg})$, volume, luas permukaan, bulk density, porositas, dan angle of repose berdasarkan hasil uji paired sample T-Test dengan tingkat signifikansi 95\%. Namun demikian sphericity dan true density biji kakao sebelum dan setelah pengeringan secara statistik tidak nyata berubah dengan alat uji yang sama.

\section{DAFTAR PUSTAKA}

Andasuryani, P.N. dan Sutan, S.M. 2015. KajianSifat-sifat Fisik buah dan Biji Kakao. Jurnal Teknologi Pertanian Andalas, 19(1): 1-9.

Anisum. 2016. Analisis Kinetika Kadar Air pada Pengeringan Biji Kakao (Theobrama Cacao Linn) dengan Menggunakan Pengering Tipe Grennhouse. Jurnal Pertanian Terpadu, 4(2): 19-29.

Anyidoho, E.K. 2015. The Effects of Moisture and Fermentation Periods on The Physical and Biochemical Properties of 'Amelonado' and 'Hybrid' Varieties of
Cocoa Beans. The Department of Agricultural Engineering of The School of Agriculture. [PhD Thesis]. University of Cape Coast.

[BPS] Badan Pusat Statistik. 2019. Statistik Kakao Indonesia 2019.

[BSN] Badan Standarisasi Nasional. 2008. SNI 012323-2008 Tentang Standar Mutu Biji Kakao. Badan Standarisasi Nasional, Jakarta.

Carr, R. L. 1976. Powder and Granule Properties and Granule Properties and Mechanism. Di dalam: Marchello, J. M. And A. Gomezplata (eds). Gass Solid Handling in The Processing Industries. Marchell Dekker, Inc, New York.

Chakraverty, A. dan Singh, R.P. 2001. Postharvest Techolology: Cereal, Pulses, Fruits and Vegetables. Science Publishers, Inc. USA: Enfield, NH.

Culver, C. A. and Wrolstad, R. E. 2008. Color Quality of Fresh and Processed Foods. ACS Symposium Series 983. ACS Division of Agricultural and Food Chemistry, Inc. American Chemical Society. Washington, DC: Oxford University Press.

Desrosier, N.W. 1988. Teknologi Pengawetan Pangan. Penerjemah M. Muljohardjo. Jakarta:UI-Press.

Deus, V.L., M.B. Cerqueira E Silva, L.F. Maciel, L.C.R. Miranda, E.Y. Hirooka, S.E. Soares, E.S. Ferreira, dan E.S. Bispo. 2018. Influence of Drying Methods on Cocoa (Theobroma cacao L.): Antioxidant Activity and Presence of Ochratoxin A. Food Sci. Technol, Campinas, 38(Suppl. 1): 278-285.

Divekar, S.P., Thakor, N.J., Mulla, H.Y., dan Sawant, M.V. 2011. Effect of Drying on Physical Properties of Nutmeg. Engineering of Technology in India, 2(1\&2):18- 23.

Filho, C.P.H; A.L.D. Gonelo; T.E. Masetto; and E.A.S. Martins. 2016. The Effect of Drying 
Temperatures and Storage of Seeds on The Growth of Soybean Seedlings. Journal of Seed Science, 38(4): 287-295.

Jain, R.K., dan Bal. S. 1997. Properties of Pearl Millet. J. agric. Engng Res, 66: 85-91.

Kaleemullah, S. dan Kailappan, R. 2003. Geometric and Morphometric Properties of Chillies. International Journal of Food Properties, 6(3): 481-498.

Koua, B.K., Koffi, P.M.E., dan Gbaha, P. 2017. Evolution of Shrinkage, Real Density, Porosity, Heat and Mass Transfer Coefficients During Indirect Solar Drying of Cocoa Beans. Journal of the Saudi Society of Agricultural Sciences, 18(1): 111.

Lasisi, D. 2014. A Comparative Study of Effects of Drying Methods on Quality of Cocoa Beans. International Journal of Engineering Research \& Technology (IJERT), 3(1): 991-996.

Mohsenin, N.N. 1986. Physical Properties of Plant and Animal Materials Volume 1: Structure, Physical Characteristics and Mechanical Properties. New York: Gordon and Breach Science Publishers.

Murad, Sukmawaty, Sabani, R., dan Putra, G.M.D. 2015. Pengeringan Biji Kemiri Pada Alat Pengering Tipe Batch Model Tungku Berbasis Bahan Bakar Cangkang Kemiri. Jurnal Ilmiah Rekayasa Pertanian dan Biosistem, 3(1): 122-127.

Ndukwu M.C. 2009. Effect of Drying Temperature and Drying Air Velocity on the Drying Rate and Drying Constant of Cocoa Bean. Agricultural Engineering International: the CIGR Ejournal. Manuscript 1091, XI April 2009.

Ndukwu M.C., Simonyan, K.J., dan Ndirika, V.I.O. 2012. Investigation of The Structural Changes of Cocoa Bean (with and without seed coat) During Convective Drying. Int J Agric \& Biol Eng, 5(3): 75-82.
Pangaribuan, S., Nuryawati, T., dan Suprapto, A. 2016. Sifat Fisik dan Mekanik Serta Pengaruh Penyosohan terhadap Sifat Fisik dan Mekanik Biji Sorgum Varietas KD 4. Prosiding Seminar Nasional Pengembangan Teknologi Pertanian Politeknik Negeri Lampung (pp. 81-86). Politeknik Negeri Lampung. 8 September 2016.

[Permentan RI] Peraturan Menteri Pertanian Republik Indonesia. Nomor 67/ Permentan/OT.140/5/2014 Tentang Persyaratan Mutu dan Pemasaran Biji Kakao. Berita Negara Republik Indonesia Tahun 2014 Nomor 679.

Risdianti, D., Murad., dan Putra, G.M.D. 2016. Kajian Pengeringan Jahe (Zingiber Officinale Rosc) Berdasarkan Perubahan Geometrik dan Warna Menggunakan Metode Image Analysis. Jurnal Ilmiah Rekayasa Pertanian dan Biosistem, 4(2): 275-284.

Senadeera W, Adiletta G, Önal B, Di Matteo M, Russo P. 2020 Influence of Different Hot Air Drying Temperatures on Drying Kinetics, Shrinkage, and Colour of Persimmon Slices. Foods, 9(1):101.

Shitanda, D., Nishiyama, Y., dan Koide S. 2002. Compressive Strength Properties of Rough Rice Considering Variation of Contact Area. Journal of Food Engineering, 53: 53-58.

Siddique, A.B. dan D. Wright. 2003. Effects of Different Drying Time and Temperature on Moisture Percentage and Seed Quality (Viability and Vigour) of Pea Seeds (Pisum sativum L.). Asian Journal of Plant Sciences, 2: 978-982.

Suherman., Purbasari, A., dan Aulia, MP. 2012. Pengaruh Suhu Udara dan Berat Sampel pada Pengeringan Tapioka Menggunakan Pengering Unggun Terfluidakan. Prosiding SNST (pp. 45-50). Semarang. Fakultas Teknik Universitas Wahid Hasyim. 
Syah, H., Yusmaniar., dan Maulana, O. 2013. Karakteristik Fisik Bubuk Kopi Arabika Hasil Penggilingan Mekanis dengan Penambahan Jagung dan Beras Ketan. Jurnal Teknologi dan Industri Pertanian Indonesia, 5(1), 32-37.
Tardzenyuy, M.E., Z. Jianguo, T. Akyene, dan M.P. Mbuwel. 2020. Improving cocoa beans value chain using a local convection dryer: A case study of Fako division Cameroon. Scientific African, 8: e00343. 